\title{
MENENTUKAN SKALA PRIORITAS SISTEM INFORMASI: Studi Kasus pada Website UPT Perpustakaan Proklamator Bung Karno
}

\author{
Fiendhy Prastika \\ fiendhyprastika@gmail.com \\ S1 Ilmu Perpustakaan \\ Fakultas Sastra Universitas Negeri Malang
}

\begin{abstract}
Abstrak: Artikel ini bertujuan memaparkan penentuan skala prioritas sistem informasi di sebuah organisasi atau perpustakaan berdasarkan kerangka matriks Warren McFarlan, yaitu Strategic System Information (SIS), Potential Strategic System Information (PSIS), Critical Information System (CIS), dan Vital Information System (VIS). Pada website UPT Perpustakaan Proklamator Bung Karno diterapkan skala prioritas karena berbagai pilihan menu yang ada dapat diukur tingkat kepentingannya. Website sendiri dijadikan sebagai Strategic Information System, lalu terdapat pilihan menu kontak sebagai Potential Strategic Information System, dan database website sebagai Critical Information System serta pilihan menu tata tertib sebagai Vital Information System. Penentuan skala prioritas sistem informasi tersebut berdasarkan pengamatan terhadap kedudukan fitur-fitur yang terdapat pada website resmi perpustakaan. Keseluruhan jenis skala prioritas tersebut terdapat pada website perpustakaan.
\end{abstract}

Kata Kunci: skala prioritas sistem informasi, sistem informasi

Abstract: This article aims to explain the determination of priority scale information systems in an organization or library based framework matrix Warren McFarlan, the Strategic Information System (SIS), Potential Strategic Information System (PSIS), Critical Information System (CIS), and Vital Information System ( VIS). On the website of Bung Karno Library Unit implemented priorities for various menu options that exist to measure the level of importance. The website itself serve as the Strategic Information System, and then there is contact menu selection as a Potential Strategic Information System, and the database website as Critical Information System as well as menu selection order as Vital Information System. Setting priorities of the information system based on observations of the position of the features found on the official website of the library. Overall the priority scale type found on the library website.

Keywords: priority scale information systems, information systems 
Perpustakaan adalah institusi pengelola karya tulis, karya cetak, dan atau karya rekam secara profesional dengan sistem yang baku guna memenuhi kebutuhan pendidikan, penelitian, pelestarian, informasi, dan rekreasi para pemustaka (UU RI No. 43 Tahun 2007). Lebih lanjut lagi, perpustakaan merupakan kumpulan bahan informasi yang terdiri dari buku dan non-buku yang disusun dengan sistem tertentu, diperuntukkan kepada pengguna jasa perpustakaan untuk dapat dimanfaatkan, akan tetapi tidak untuk dijadikan hak milik baik sebagian maupun keseluruhan (Huda, 2007).

Dari konsep tersebut dapat disimpulkan bahwa perpustakaan dijadikan wadah berbagai macam ilmu dan informasi penting bagi khalayak, dan untuk mengelolanya diperlukan sebuah sistem pengelolaan yang baik serta fasilitas yang memadai agar menunjang mutu pelayanan perpustakaan itu sendiri.

Sistem informasi perpustakaan banyak bermunculan untuk memenuhi kebutuhan akan kemudahan kinerja para staf dan efisiensi waktu yang lebih baik dibanding sistem manual (manual system). Pengintegrasian database, penggunaan peralatan elektronik, dan proses operasional yang telah terkomputerisasi sering disebut sebagai otomasi perpustakaan. Otomasi perpustakaan adalah proses pengelolaan perpustakaan dengan mempergunakan teknologi informasi sebagai media penunjangnya. Proses otomasi kemudian menghadirkan dua buah konsep sistem informasi pada perpustakaan yaitu sistem informasi perpustakaan yang berbasis desktop (desktop based) dan sistem informasi perpustakaan yang berbasis web (web based).

Kedua konsep sistem informasi perpustakaan (berbasis desktop dan berbasis web) mempunyai tujuan yang sama yaitu efektivitas dan efisiensi pada proses otomasi perpustakaan. Kedua konsep tersebut memiliki perbedaan pada media yang digunakan. Sistem informasi berbasis desktop memberikan kemudahan para staf perpustakaan dalam pelayanan karena meskipun telah menggunakan sarana komputer, namun server yang digunakan sebatas lokal dan tidak dapat diakses user di luar perpustakaan. Sedangkan sistem informasi berbasis web adalah sistem akses informasi perpustakaan yang dapat diakses user dimanapun karena media yang digunakan adalah internet.

UPT Perpustakaan Proklamator Bung Karno adalah salah satu 
perpustakaan yang sistem informasinya telah berbasis web (web based). Website resmi perpustakaan dapat diakses dimanapun tanpa terkendala jarak dan waktu. Pencarian koleksi maupun pendaftaran anggota dapat dilakukan pengguna secara langsung melalui website perpustakaan. Sistem informasi berbasis web ini diharapkan dapat memberi kemudahan baik kepada para staf maupun semua pihak tanpa harus mendatangi perpustakaan secara langsung serta dapat mengaksesnya kapan pun dan dimanapun serta dapat menjawab semua permasalahan yang muncul.

Lebih lanjut lagi, pada sistem informasi dapat dikategorikan ke dalam empat kelompok diantaranya: (a) Strategic Information System, (b) Potential Strategic Information System, (c) Critical Information System, dan (d) Vital Information System. Skala prioritas sistem informasi menurut Warren McFarlan (1983) tersebut dapat digunakan untuk mengukur sejauh mana tingkat kepentingan sistem informasi pada suatu perpustakaan. Meskipun UPT Perpustakaan Proklamator Bung Karno telah menggunakan sistem informasi berbasis web, namun tidak ada pemisahan atau prioritas pada sistem berbasis web tersebut. Artikel ini akan membahas "Menentukan Skala Prioritas Sistem Informasi pada UPT Perpustakaan Proklamator Bung Karno Blitar-Jawa Timur"

\section{PEMBAHASAN}

\section{a. Landasan Teori}

Sistem informasi perpustakaan adalah suatu penerapan teknologi informasi yang digunakan sebagai sistem informasi manajemen perpustakaan. Bidang pekerjaan yang dapat diintegrasikan dengan sistem informasi perpustakaan adalah pengadaan, inventarisasi, katalogisasi, sirkulasi bahan pustaka, pengelolaan anggota, statistik, dan lain sebagainya dan sering disebut sebagai bentuk otomasi perpustakaan (Arif, 2003).

Tujuan sistem informasi perpustakaan menurut John Corbin (1985) antara lain:

1. Mempercepat layanan informasi yang diberikan

2. Meringankan beban tugas pustakawan/staf perpustakaan terhadap pekerjaan yang bersifat pengulangan dan rutin (klerikal) 
3. Menghemat waktu dan tenaga sehingga memberikan hasil kerja yang konsisten

4. Meningkatkan kerjasama antar layanan/bagian ataupun antar perpustakaan

5. Memberikan layanan yang lebih efektif kepada pemakai

Penentuan skala prioritas sistem informasi di sebuah organisasi atau perusahaan dapat menggunakan kerangka matriks Warren McFarlan. Matriks ini terbagi menjadi empat jenis yaitu Strategic System Information (SIS), Potential Strategic System Information (PSIS), Critical Information System (CIS), dan Vital Information System (VIS). Matriks tersebut menunjukkan tingkat kepentingan sistem informasi yang ada di organisasi atau perpustakaan tersebut. Untuk lebih jelasnya dapat dilihat pada bagan berikut (Lihat Bagan 1).

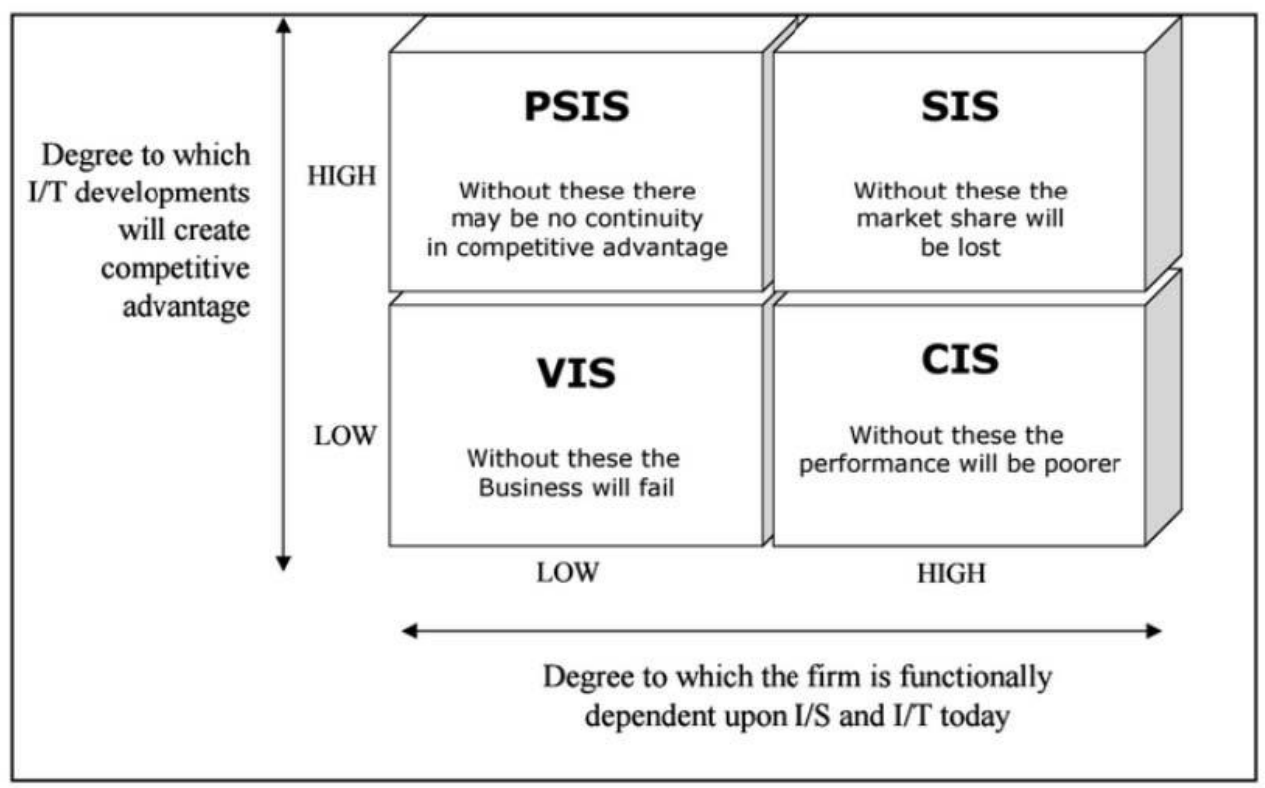

\section{Bagan 1. Kerangka Skala Prioritas Sistem Informasi Warren McFarlan,} 1983.

Pada bagan di atas dapat dijelaskan bahwa Strategic System Information (SIS) memiliki kedudukan atau peranan yang paling penting dalam sebuah sistem informasi. Selanjutnya diikuti oleh Potential Strategic System Information (PSIS) dan Critical Information System (CIS) dan yang terakhir adalah Vital Information System (VIS). Bagan tersebut menunjukkan sejauh mana perkembangan teknologi informasi akan menciptakan keunggulan yang kompetitif dan sejauh mana perpustakaan secara fungsional bergantung pada sistem informasi dan teknologi 
informasi.

Pertama adalah Strategic System Information (SIS), yaitu suatu sistem memberikan keunggulan yang kompetitif bagi perpustakaan sehingga dapat menjadi senjata utama untuk mengalahkan pesaing atau kompetitor. Secara fungsional sebuah perpustakaan tidak dapat beroperasi tanpa dilengkapi dengan sistem informasi. Namun bagi perpustakaan yang tidak memiliki Strategic System Information (SIS) yang baik, maka yang akan terjadi adalah perpustakaan tersebut akan kehilangan market share secara signifikan. Market share yang dimaksud yaitu persentase total dari suatu perpustakaan dengan total jasa atau pemenuhan kebutuhan para penggunanya.

Kedua adalah Potential Strategic System Information (PSIS), yaitu jenis sistem yang memberikan keunggulan kompetitif bagi perpustakaan tetapi memiliki sifat nice to have (additional). Sebenarnya tanpa sistem ini perpustakaan dapat beroperasional dengan baik, namun perpustakaan yang bersangkutan dapat kehilangan keunggulan kompetitif terhadap perpustakaan lainnya. Dampak yang terjadi adalah para pengguna perpustakaan akan kecewa dan bisa saja terjadi penurunan pengguna perpustakaan tersebut.

Ketiga adalah Critical Information System (CIS), yaitu spesifikasi sistem yang baik, kemampuan, dan aktivitas yang penting dibutuhkan oleh kompetitor untuk dapat merencanakan dan bertindak secara efektif dan dapat menjamin misi dan prestasi. Apabila perpustakaan tidak memiliki sistem ini, kemungkinan terbesarnya akan menurunkan kinerja perpustakaan (library performance) dan menyebabkan interaksi dengan pelanggan (mengecewakan pelanggan).

Keempat adalah Vital Information System (VIS), yaitu sebuah sistem yang keberadaannya mutlak dibutuhkan sebuah perpustakaan, karena memiliki karakteristik sebagai penunjang kegiatan sehari-hari. Namun secara prinsip sistem ini tidak memiliki fungsi yang strategis, akan tetapi dibutuhan sebagai penunjang kegiatan administratif.

Strategic System Information (SIS), Potential Strategic System Information (PSIS), Critical Information System (CIS), dan Vital Information System (VIS) dibutuhkan oleh perpustakaan untuk menentukan skala prioritas sistem informasi. Namun tidak semua perpustakaan perlu menerapkan 
keseluruhan sistem tersebut. Hal ini disebabkan oleh masing-masing kebutuhan dan jenis perpustakaan yang berbeda-beda. Kerangka matrik McFarlan yang telah dijelaskan sebelumnya diproyeksikan dapat membantu tingkat prioritas sistem informasi dalam sebuah organisasi atau perpustakaan. Terutama dalam perencanaan sebuah proyek yang dimana proyek tersebut harus dianalisa biaya atau keuntungannya. Selain itu perlu diperhatikan dampak jika perpustakaan yang bersangkutan tidak memiliki sistem informasi yang baik karena akan berpengaruh pada operasional perpustakaan tersebut kedepannya.

\section{b. Metode Analisis}

Metode yang digunakan adalah analisis data secara kualitatif dengan jenis deskriptif studi kasus. Analisis kualitatif atau naturalistic inquiry adalah prosedur penelitian yang menghasilkan data deskriptif berupa kata-kata tertulis atau lisan dari orang-orang dan perilaku yang dapat diamati (Bodgan dalam Suharsaputra, 2012). Dipilih metode kualitatif agar diperoleh informasi sesuai dengan tujuan dari penelitian ini. Selain itu menggunakan jenis penelitian deskriptif studi kasus dengan menguraikan masalah yang dikaji pada sistem informasi yang digunakan di UPT Perpustakaan

Proklamator Bung Karno. Menurut Wiyono (2007:78), menyatakan bahwa "studi kasus merupakan serangkaian kegiatan penyelidikan untuk mendeskripsikan dan menganalisis secara intensif dan terperinci suatu gejala atau unit sosial tertentu seperti individu, kelompok, komunitas atau lembaga". Dengan menggunakan jenis penelitian ini peneliti bisa memahami obyek yang diteliti secara khusus serta peneliti bisa mencari pemecahan masalah secara mendalam.

\section{c. Hasil analisis}

\section{Website sebagai Strategic System Information (SIS)}

Pada UPT Perpustakaan Proklamator Bung Karno, wesbite memiliki peranan penting sebagai salah satu sarana promosi dan juga user education (pendidikan pemakai). Website berisi hal-hal terkait layanan, koleksi, galeri, artikel dan kontak yang terdapat di perpustakaan. Online Public Access Catalogue (katalog online), pendaftaran keanggotaan, referensi dan e-resources juga terdapat pada website. Apabila perpustakaan menghentikan operasional website, dapat dimungkinkan pengguna akan merasa kesulitan dalam menelusur informasi di perpustakaan 
karena di dalam website telah mencakup informasi-informasi penting terkait perpustakaan.

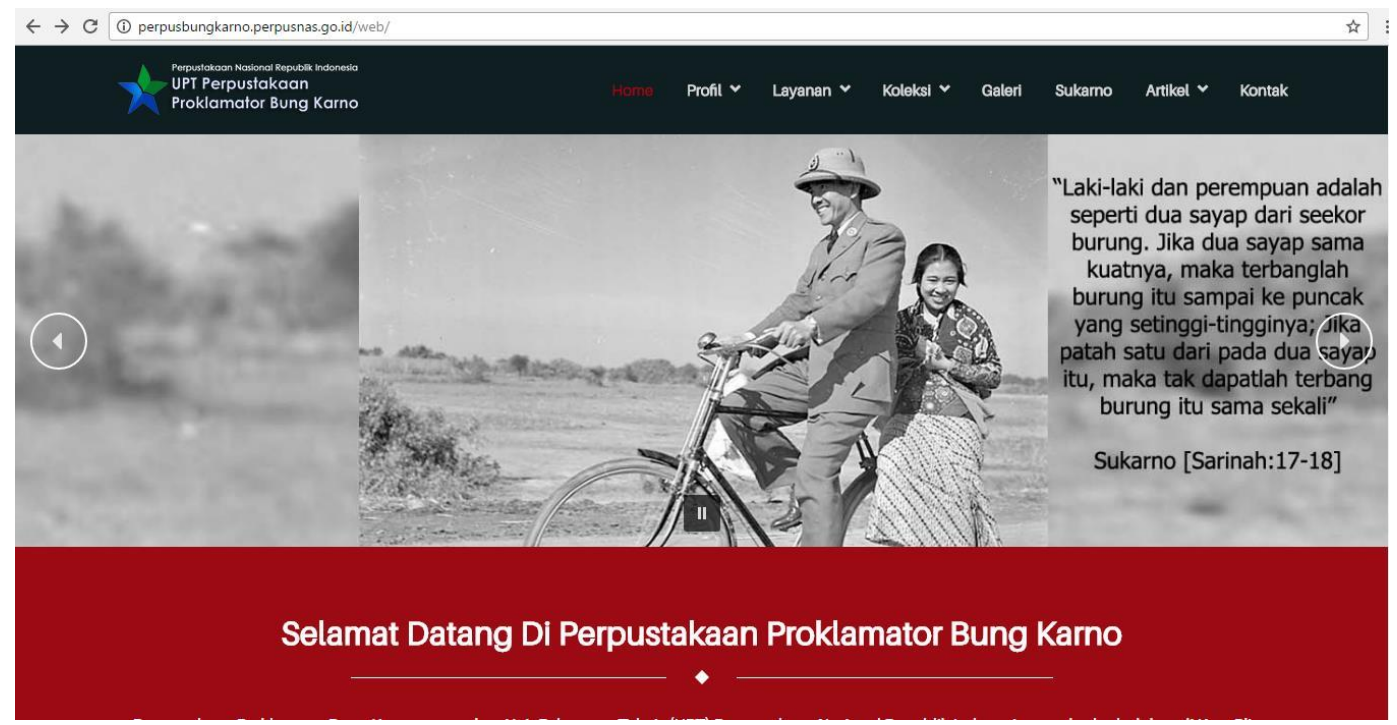

Gambar 1. Website UPT Perpustakaan Proklamator Bung Karno

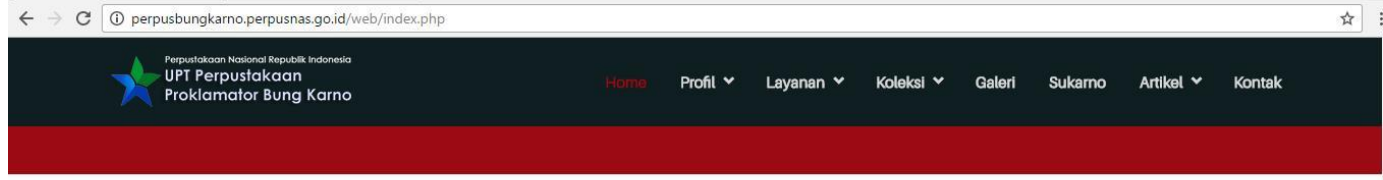

Layanan Kami

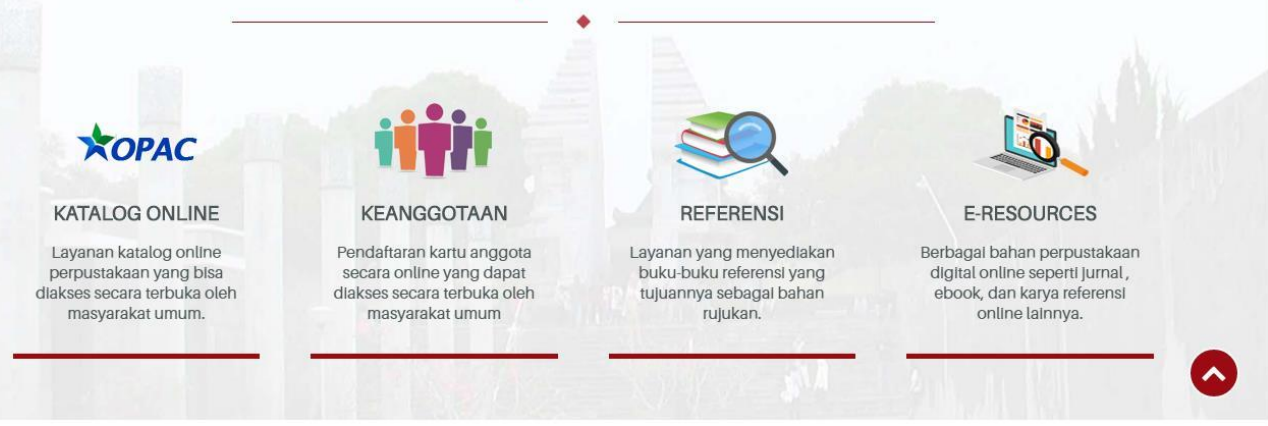

Gambar 2. Integrasi Layanan pada Website UPT Perpustakaan Proklamator Bung Karno

\section{Kontak sebagai Potential Strategic System Information (PSIS)}

Pada website UPT Perpustakaan Proklamator Bung Karno terdapat kontak yang ditujukan untuk pengguna apabila menemui kesulitan maupun akan menghubungi langsung pihak petugas perpustakaan ketika menemui kesulitas. Namun, apabila perpustakaan tersebut menghentikan layanan ini, dapat 
dimungkinkan pengguna akan merasa kecewa, karena layanan ini lebih efektif daripada harus datang ke perpustakaan bertanya langsung kepada pustakawan.

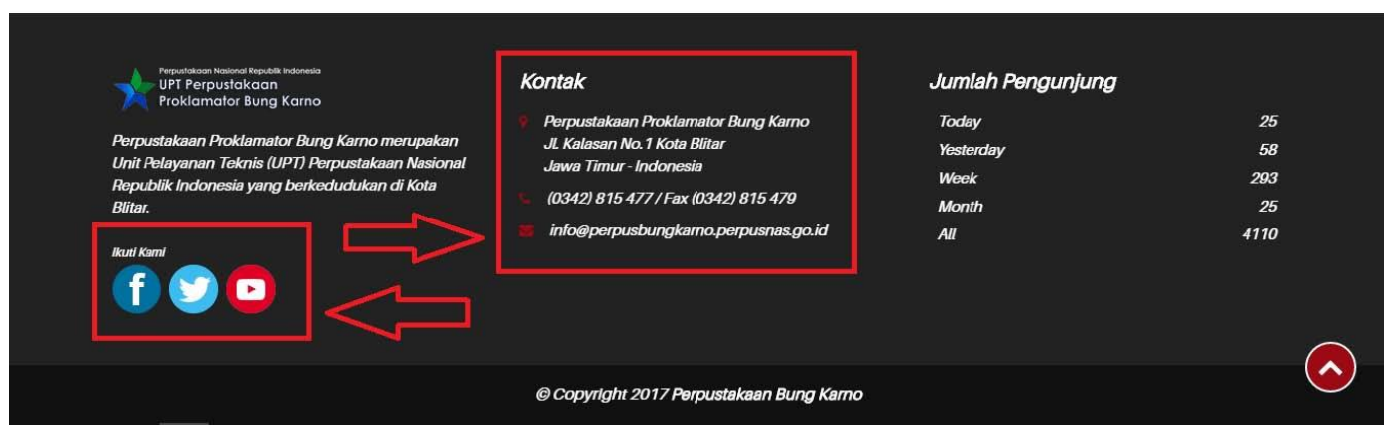

Gambar 3. Kontak \& Link Sosmed pada Website UPT Perpustakaan Proklamator Bung Karno

Selain itu, pengguna juga dapat mengirimkan pertanyaan dengan menggunakan pilihan menu kontak kami, isi dari form kontak kami adalah sebagai berikut.

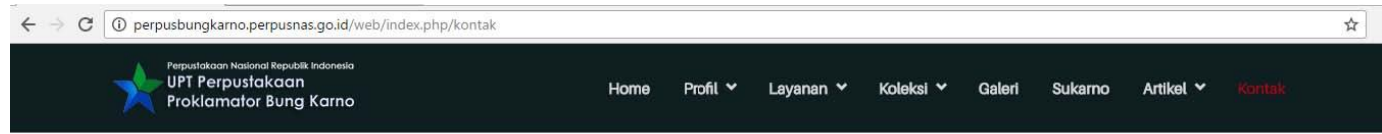

Kontak Kami

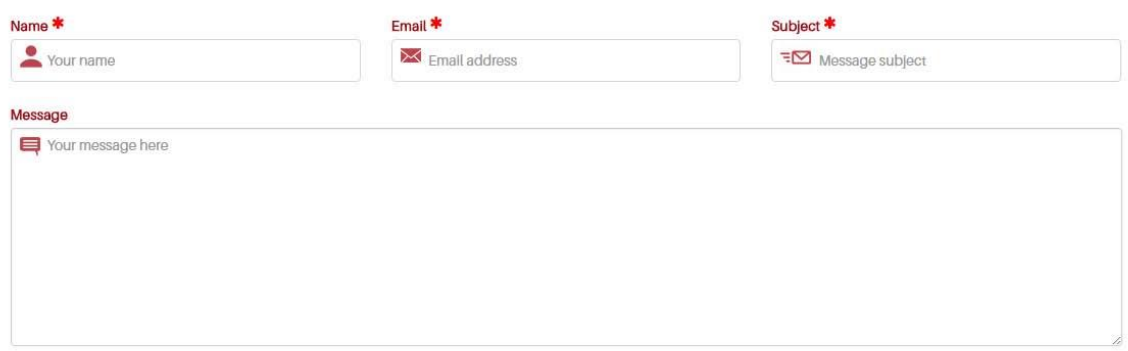

SEND MESSAGE

Gambar 4. Kontak Kami pada Website UPT Perpustakaan Proklamator Bung Karno

\section{Database Website sebagai Critical Information System (CIS)}

Dapat dicontohkan pada sebuah perpustakaan yang memunyai sistem database atau program untuk mengelola perpustakaan. Sistem tersebut diterapkan sesuai dengan jenis dan tingkat kebutuhan serta bidang perpustakaan. Sistem yang sesuai dengan jenis dan kebutuhan akan memberikan kepuasan pengguna, karena pengguna dapat menggunakan sistem dengan baik sekalipun pengguna tidak 
mengetahui tentang sistem tersebut. Hal ini disebabkan karena pengguna sebagai pemakai dan pihak yang menerima layanan perpustakaan. Database website UPT Perpustakaan Proklamator Bung Karno mencakup integrasi dari database OPAC, keanggotaan, referensi, e-resources yang kesemuanya dapat diakses dari website resmi perpustakaan.

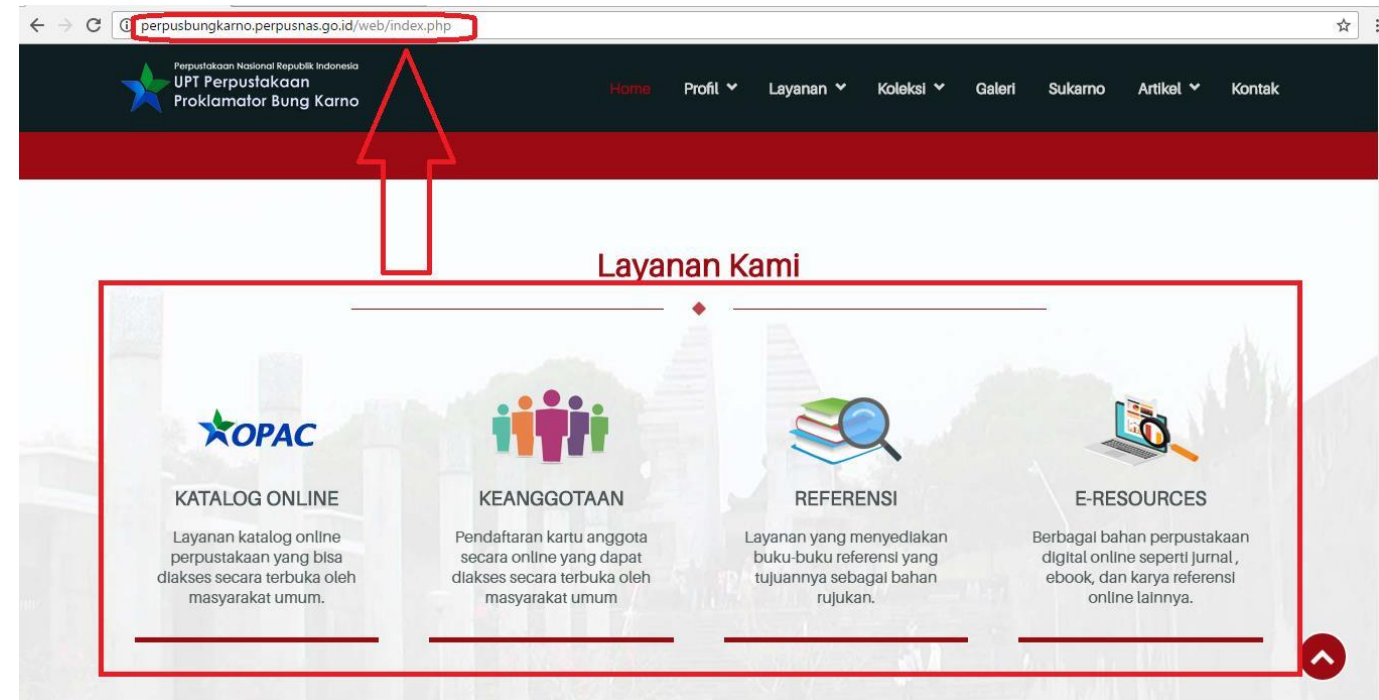

\section{Gambar 5. Database Website yang Terintegrasi pada Website UPT Perpustakaan Proklamator Bung Karno}

\section{Menu Tata Tertib sebagai Vital Information System (VIS)}

Perpustakaan dapat menerapkan sistem informasi ini walaupun kedudukannya tidak mutlak dibutuhkan. Namun, tetap disediakan untuk menunjang kegiatan sehari-hari (administratif) terutama perpustakaan yang memiliki skala besar. Pada website UPT Perpustakaan Proklamator Bung Karno terdapat pilihan menu tata tertib. Pada menu tata tertib ini terdapat berbagai informasi seputar tata tertib pengunjung, tata tertib keanggotaan, tata tertib peminjaman dan pengembalian koleksi buku. Pilihan menu ini tidak mutlak diperlukan untuk operasional perpustakaan, namun pengguna atau anggota baru dapat memanfaatkannya sebagai user education karena berisi tentang tata tertib yang harus mereka patuhi apabila berada di perpustakaan. 


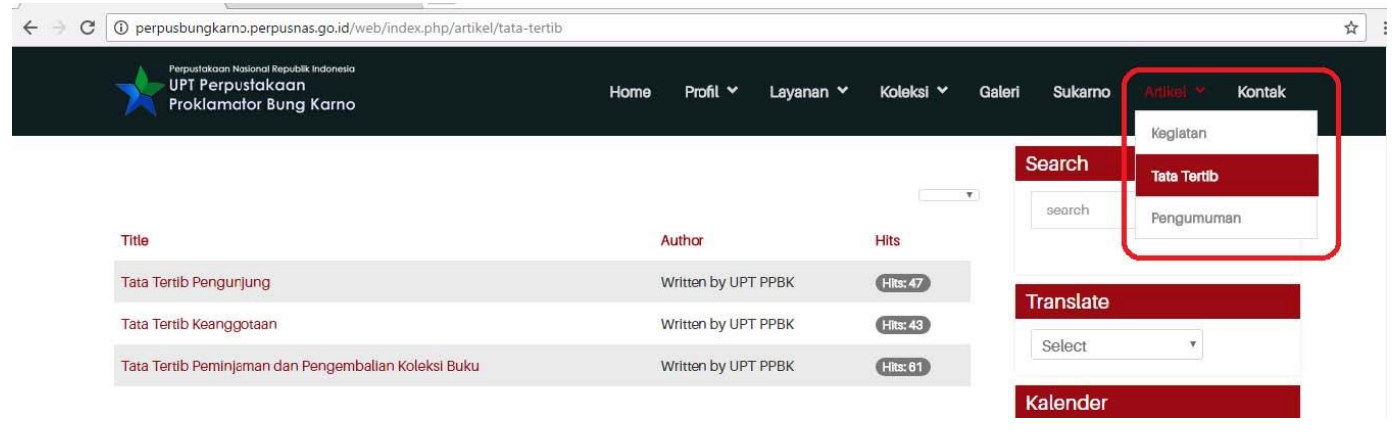

Gambar 6. Tata Tertib pada Website UPT Perpustakaan Proklamator Bung Karno

\section{PENUTUP}

Berdasarkan skala prioritas Sistem Informasi Warren McFarlan (1983) yang membagi sistem informasi menjadi empat jenis yaitu Strategic System Information (SIS), Potential Strategic System Information (PSIS), Critical Information System (CIS), dan Vital Information System (VIS), pada website UPT Perpustakaan Proklamator Bung Karno, sistem informasi dapat dibagi menjadi empat berdasar tingkat kepentingan atau skala prioritasnya. Pertama adalah website itu sendiri sebagai Strategic System Information (SIS) yaitu center atau pusat dari web based yang diterapkan pihak perpustakaan. Website berisi seluruh informasi perpustakaan mulai dari layanan, koleksi, kegiatan, tata tertib, pengumuman, OPAC, referensi, keanggotaan, e-resources, kontak, alamat dan sebagainya. Website sangat penting keberadaannya selain karena berisi informasi-informasi penting, juga menjadi salah satu sarana user education apabila terdapat pengguna atau anggota baru.

Kedua adalah kontak sebagai Potential Strategic System Information (PSIS). Pada website UPT Perpustakaan Proklamator Bung Karno terdapat kontak yang ditujukan untuk pengguna apabila menemui kesulitan maupun akan menghubungi langsung pihak petugas perpustakaan ketika menemui kesulitan. Namun, apabila perpustakaan tersebut menghentikan layanan ini, dapat dimungkinkan pengguna akan merasa kecewa, karena layanan ini lebih efektif daripada harus datang ke perpustakaan bertanya langsung kepada pustakawan. Selain itu, pengguna juga dapat mengirimkan pertanyaan dengan menggunakan pilihan menu kontak kami, isi dari form kontak kami akan dijawab langsung oleh 
pustakawan dan dikirimkan ke email pengirim form.

Ketiga adalah database website sebagai Critical Information System (CIS). Database website UPT Perpustakaan Proklamator Bung Karno mencakup integrasi dari database OPAC, keanggotaan, referensi, e-resources yang kesemuanya dapat diakses dari website resmi perpustakaan.

Keempat adalah menu Tata Tertib sebagai Vital Information System (VIS). Perpustakaan dapat menerapkan sistem informasi ini walaupun kedudukannya tidak mutlak dibutuhkan. Namun, tetap disediakan untuk menunjang kegiatan sehari-hari (administratif) terutama perpustakaan yang memiliki skala besar. Pada menu tata tertib ini terdapat berbagai informasi seputar tata tertib pengunjung, tata tertib keanggotaan, tata tertib peminjaman dan pengembalian koleksi buku. Pilihan menu ini tidak mutlak

diperlukan untuk operasional perpustakaan, namun pengguna atau anggota baru dapat memanfaatkannya sebagai user education karena berisi tentang tata tertib yang harus mereka patuhi apabila berada di perpustakaan.

Jadi dapat disimpulkan bahwa pada website UPT Perpustakaan Proklamator Bung Karno dapat diterapkan skala prioritas karena berbagai pilihan menu yang ada dapat diukur tingkat kepentingannya. Website sendiri dijadikan sebagai Strategic Information System, lalu terdapat pilihan menu kontak sebagai Potential Strategic Information System, dan database website sebagai Critical Information System serta pilihan menu tata tertib sebagai Vital Information System. Penentuan skala prioritas sistem informasi tersebut berdasarkan pengamatan terhadap kedudukan fitur-fitur yang terdapat pada website resmi perpustakaan. Keseluruhan jenis skala prioritas tersebut terdapat pada website perpustakaan karena UPT Perpustakaan Proklamator Bung Karno dapat dikatakan sebagai perpustakaan berskala besar yang sistem informasinya telah terorganisir secara baik dan dijadikan evaluasi pihak perpustakaan untuk mengembangkan kinerja perpustakaan. 


\section{DAFTAR PUSTAKA}

Arif, Ikhwan. 2003. Konsep dan Perencanaan dalam Automasi Perpustakaan. UMM: Malang

Corbin, John. 1985. Developing Computer-Based Library System. Oryx Press, Phoenix

Indrajit, Richardus Eko. 2012. Skala Prioritas Sistem Informasi. (Online), https://www.academia.edu/14337525/Skala_Prioritas_Sistem_Informasi, diunduh pada 5 Maret 2017.

McFarlan, Warren F, and James L McKenney. 1983. Corporate Information Systems Management, Homewood, Illinois: Richard D Irwin, Inc.

Suharsaputra, Uhar. 2012. Metode Penelitian Kualitatif, Kuantitatif dan Tindakan. Bandung : PT Refika Aditama

Undang-Undang Republik Indonesia Nomor 43 Tahun 2007 tentang Perpustakaan

Wiyono, Bambang Budi. 2007. Metode Penelitian (Pendekatan Kuantitatif, Kualitatif, dan Action Research). Malang : Fakultas Ilmu Pendidikan Universitas Negeri Malang 